\title{
HUBUNGAN DIMENSI RELIABILITY PADA PERSEPSI DAN KEPUASAAN PASIEN ANC DI PUSKESMAS WILAYAH SURAKARTA
}

\author{
Umi Khasanah $^{1)}$, Sulistyaningsih ${ }^{2)}$, Suryo Ediyono ${ }^{3)}$ \\ ${ }^{1}$ Universitas Muhammadiyah Semarang \\ ${ }^{2}$ Universitas 'Aisyiyah Yogyakarta \\ ${ }^{3}$ Universitas Sebelas Maret Surakarta \\ e-mail: Umikhasanah@unimus.ac.id
}

\begin{abstract}
ABSTRAK
Persepsi kualitas pelayanan berhubungan dengan kepuasan pasien. Pelayanan Antenatal Care yang berkualitas dapat memberikan pelayanan yang dibutuhkan ibu hamil sehingga resiko tinggi atau komplikasi dapat dicegah sejak dini. Pelayanan yang diberikan oleh tenaga kesehatan untuk ibu hamil sesuai dengan standar pelayanan ANC yang telah ditetapkan minimal 4 kali selama hamil (1 kali pada trimester pertama, 1 kali pada trimester kedua dan 2 kali pada trimester ketiga). Di dalam dimensi reliability mencangkup kemampuan memberikan pelayanan kepada pasien dengan memuaskan secara segera dan tepat.. Tujuan penelitian untuk menganalisis hubungan dimensi reliability pada persepsi dan kepuasan pasien selama kunjungan pelayanan ANC di Puskesmas Wilayah Surakarta. Penelitian analitik ini dengan pendekatan cross sectional menggunakan data kuantitatif. Jumlah sampel 108 dari 2 puskesmas yakni Kratonan dan Gajahan dengan teknik purposive sampling. Pengumpulan data dilakukan dengan menggunakan kuesioner untuk ibu hamil. Analisis data menggunakan Chi-Square untuk menguji hubungan. Terdapat hubungan yang signifikan antara persepsi dimensi reliability dan kepuasan pasien pada pelayanan ANC dengan $\mathrm{p}=0,000$ dan $\mathrm{PR}=17,875$. Persepsi ibu hamil yang baik bergantung pada prosedur dan administrasi saat pelayanan serta sikap bidan atau pemberi pelayanan ANC sesuai kebutuhan masing-masing ibu hamil.
\end{abstract}

Kata kunci: antenatal care, kepuasan, reliability

\begin{abstract}
Perceptions of service quality are related to patient satisfaction. Quality Antenatal Care Services can provide the services pregnant women need so that high risks or complications can be prevented from an early age. Services provided by health personnel for pregnant women are in accordance with the ANC service standards which have been set at least 4 times during pregnancy (1 time in the first trimester, 1 time in the second trimester and 2 times in the third trimester). In the dimension of reliability, it covers the ability to provide services to patients satisfactorily immediately and precisely. The objective was to analyze the relationship between reliability dimensions on patient perceptions and satisfaction during ANC service visits at the Surakarta Health Center. The method used was analytical research with a cross sectional approach using quantitative data. The number of samples was 108 from 2 health centers namely Kratonan and Gajahan with purposive sampling technique. Data collection was carried out using a questionnaire for pregnant women. Data analysis using Chi-Square to test the relationship. There is a significant relationship between perceived dimensions of reliability and patient satisfaction at ANC services with $p=0.000$ and $P R=17.875$. The perception of good pregnant women depends on the procedures and administration of the service as well as the attitude of the midwife or ANC service provider according to the needs of each pregnant woman.
\end{abstract}

Keyword: antenatal care, reliability, satisfaction 


\section{PENDAHULUAN}

Perkembangan masyarakat yang semakin kritis dalam berpikir dan menilai, mutu pelayanan juga menjadi sorotan berdasarkan persepsi mereka apalagi untuk pelayanan sekarang ini terutama untuk pelayanan medis. Ukuran keberhasilan penyelenggaraan ditentukan oleh tingkat kepuasan penerima pelayanan. Hal itu mempengaruhi pengambilan keputusan pemanfaatan ulang yang sifatnya terus-menerus terhadap pembelian jasa yang sama dan akan mempengaruhi penyampaian pesan/kesan kepada pihak/orang lain tentang pelayanan kesehatan yang diberikan (Mbachu, Dim and Ezeoke, 2017). Tingkat kepuasan pelanggan Rkanlitiamėnipmagapakản pketditiurramalitik dengan pendekatan Cross Sectional. Penelitian pemeriksaan Antenatal.

Menurut standar WHO, ibu hamil mendapatkan pelayanan ANC minimal 4 kali selama kehamilannya, yaitu 1 kali pada trimester pertama, 1 kali pada trimester ke dua dan 2 kali pada trimester ke tiga untuk memantau keadaan ibu dan janin secara seksama sehingga dapat mendeteksi secara lebih awal atau dini serta dapat memberikan intervensi yang lebih tepat (WHO, 2016).

Peraturan Menteri Kesehatan RI Nomor 43 tahun 2016, tentang standar pelayanan kesehatan minimal di bidang kesehatan di Kabupaten/kota khususnya pelayanan kesehatan ibu dan anak sebagai target tahun 2015 berupa cakupan kunjungan ibu hamil K1 dan K4. K1 merupakan kunjungan ibu hamil yang pertama kali pada masa kehamilan. Untuk K4 kontak minimal dilakukan 4 kali selama masa kehamilan untuk mendapatkan pelayanan Antenatal, yang terdiri atas minimal satu kali kontak pada trimester pertama, satu kali pada trimester kedua, dan dua kali pada trimester ketiga (Permenkes, 2016).
Persepsi mutu pelayanan berkaitan dengan kepuasan pasien. Pelayanan yang bermutu dan memberikan pelayanan yang dibutuhkan ibu hamil akan memberikan kepuasan pada ibu yang melakukan ANC (Azwar, 2010). Di dalam dimensi reliability meliputi kemampuan memberikan pelayanan kepada pasien dengan memuaskan secara segera dan tepat (Ravichandran, 2010; Papanikolaou and Zygiaris, 2014). Hal tersebut dibuktikan dengan cara berpenampilan dan berpakaian bersih serta rapi, lengkap dengan identitas petugas yang percaya diri dan ramah, sopan dan menghormati pasien.

\section{METODE PENELITIAN}

analitik dengan pendekatan cross sectional menggunakan data kuantitatif. Populasinya semua ibu hamil yang melakukan kunjungan ANC di Puskesmas sesuai kriteria selama bulan Januari-Maret 2018 dengan jumlah sampel 108 dari 2 puskesmas yakni Kratonan dan Gajahan. Teknik pengambilan sampling menggunakan teknik purposive sampling. Pengumpulan data dilakukan dengan menggunakan kuesioner untuk ibu hamil. Analisis data menggunakan Chi-Square untuk menguji hubungan antara kedua variabel. 


\section{HASIL DAN PEMBAHASAN}

Tabel 1

Hubungan dimensi Reliability pada persepsi dan kepuasaan pasien ANC di Puskesmas Wilayah Surakarta tahun 2018

\begin{tabular}{|c|c|c|c|c|c|c|c|c|}
\hline \multirow{3}{*}{ Reliability } & \multicolumn{4}{|c|}{$\begin{array}{c}\text { Ibu yang Memilih } \\
\text { Kepuasan }\end{array}$} & \multirow{2}{*}{\multicolumn{2}{|c|}{ Total }} & \multirow{3}{*}{$P$-value } & \multirow{3}{*}{$P R(C I)$} \\
\hline & \multicolumn{2}{|c|}{ Rendah } & \multicolumn{2}{|c|}{ Tinggi } & & & & \\
\hline & $\mathrm{n}$ & $\%$ & $\mathrm{n}$ & $\%$ & $\mathrm{n}$ & $\%$ & & \\
\hline Tidak baik & 52 & 81,3 & 12 & 18,8 & 64 & 100 & & \\
\hline baik & 2 & 4,5 & 42 & 95,5 & 44 & 100 & 0,000 & 17,875 \\
\hline Jumlah & 58 & 61,1 & 42 & 38,9 & 108 & 100 & & \\
\hline
\end{tabular}


Hasil analisis pada tabel 1 menyatakan bahwa terdapat hubungan yang signifikan antara persepsi dimensi reliability dan kepuasan pasien pada pelayanan ANC dengan $\mathrm{p}=0,000$ dan $\mathrm{PR}=17,875$. Persepsi ibu hamil yang baik bergantung pada prosedur dan administrasi saat pelayanan serta sikap bidan atau pemberi pelayanan ANC sesuai kebutuhan masing-masing ibu hamil. Persepsi tidak baik pada ibu hamil akan mengurangi tingkat kepuasan dalam pelayanan sebesar 17,875 kali dibandingkan ibu hamil dengan persepsi baik.

Dimensi reliability yang memiliki nilai kesesuaian (tingkat kepuasan) terbesar adalah tentang bidan memberikan pelayanan ANC sesuai dengan kebutuhan masing-masing ibu hamil (Heaman $e t$ $a l ., 2014)$. Item yang memiliki nilai kesesuaian terkecil adalah item tentang prosedur dan administrasi saat pelayanan. Pasien yang datang ke Puskesmas untuk melakukan pemeriksaan hamil membutuhkan bantuan tenaga kesehatan untuk mengetahui kondisi kehamilannya serta keadaan janin dalam rahimnya. Pasien berharap saat membutuhkan pelayanan kesehatan pada umumnya dan pelayanan ANC pada khususnya, prosedur pelayanan tidak terlalu rumit (Do et al., 2017).

Prosedur pelayanan ANC di Puskesmas, dimulai dari ketika pasien datang sampai dengan pasien pulang. Pasien mengambil nomor antrian pada mesin antrian sampai sampai kalau ada pemanggilan nomor antrian sesuai yang didapatkan kemudian mendaftar ke loket pendaftaran. Setelah pasien mendaftar di loket pendaftaran dan melengkapi administrasi, pasien menyerahkan nomer register rekam medik, berdasarkan nomer rekam medik, petugas loket pendaftaran mencari kartu rekam medik. Pasien kemudian menunggu di ruang tunggu sementara petugas menyerahkan kartu rekam medik ke pelayanan KIA dan diterima oleh Bidan yang bertugas melakukan pelayanan ANC. Pemeriksaan pendahuluan yang dilaksanakan oleh Bidan meliputi : anamnesa, pengukuran tekanan darah, pengukuran lingkar lengan (untuk pasien kunjungan pertama) dan penimbangan berat badan (Amini et al., 2019).

Setelah pemeriksaan pendahuluan, pasien diperiksa oleh Bidan untuk dilakukan pengukuran fundus, mengetahui letak dan denyut jantung janin. Untuk pemeriksaan penunjang lainnya misalnya pemeriksaan laboratorium akan diberikan surat pengantar ke bagian laboratorium. Bidan kemudian membuat resep sesuai dengan dengan kebutuhan ibu hamil. Pasien menunggu di depan ruang obat/apotek setelah menyerahkan resep ke petugas apotek. Petugas apotik menyiapkan obat-obatan berdasarkan resep. Setelah obat tersedia, pasien dipanggil dan diberi penjelasan cara penggunaan obat dan pasien bisa pulang.

Pada saat pasien datang, pasien berharap langsung ditangani oleh tenaga kesehatan (Moller et al., 2017) dan kewajiban mendaftar di ruang pendaftaran bukan pada pasien melainkan pada keluarga yang mengantar pasien bila ada, sehingga proses awal dari pasien datang ke ruang pelayanan ANC tidak membutuhkan waktu yang lama karena prosedur pelayanan berpengaruh besar terhadap kecepatan pelayanan (Tenkorang, 2016). Harapan pasien dan keluarga pada prosedur pelayanan adalah pasien tidak mengalami kesulitan atau membutuhkan waktu yang lama dan antrian yang panjang untuk mendaftar sebagai pasien baru karena keharusan untuk menunggu (Mikrajab and Rachmawati, 2016), tidak berdaya dan merasa terlantar adalah salah satu pengalaman yang 
membuat orang sangat frustasi (Nwaeze et al., 2013; Oladapo and Osiberu, 2015).

$$
\text { Pada dimensi reliability }
$$

berdasarkan tingkat kesesuaian pada dimensi ini cukup tinggi pada item dimensi reliability terkait pelayanan bidan dalam pelayanan ANC yang sesuai kebutuhan ibu hamil namun melihat pemeriksaan pendahuluan yang dilakukan oleh Bidan sebelum pelayanan ANC yang lebih lanjut ada satu pemeriksaan awal yang sering tidak dilakukan bidan secara rutin sehingga hanya pada saat kunjungan pertama dan bila ada keluhan atau gejala saja yakni terkait pengukuran suhu tubuh. Pengukuran suhu tubuh adalah hal penting sebagai penatalaksanaan deteksi dini atas komplikasi yang bisa terjadi pada ibu hamil dan bisa membahayakan ibu

\section{KESIMPULAN}

Ada hubungan yang signifikan antara persepsi dimensi reliability dan kepuasan pasien pada pelayanan ANC. Sebagian besar ibu hamil yang melakukan kunjungan ANC menyatakan persepsi tidak baik pada dimensi reliability dengan menyatakan kepuasaan yang rendah. Pasien yang datang ke Puskesmas untuk melakukan pemeriksaan hamil membutuhkan bantuan tenaga kesehatan untuk mengetahui kondisi kehamilannya serta keadaan janin dalam rahimnya. Pasien berharap saat membutuhkan pelayanan kesehatan pada umumnya dan pelayanan ANC pada khususnya, prosedur pelayanan tidak terlalu rumit. Persepsi ibu hamil yang baik bergantung pada prosedur dan administrasi saat pelayanan serta sikap bidan atau pemberi pelayanan ANC sesuai kebutuhan masing-masing ibu hamil. hamil dan janin (Rahman, Ngadan and Arif, 2016). Pengukuran suhu tubuh seharusnya dilakukan secara rutin pada setiap kunjungan ANC (Manzi et al., 2018). Hal tersebut tertera pada pedoman ANC Terpadu yang dikeluarkan oleh Kementrian Kesehatan tahun 2015.

Dimensi mutu pelayanan ini merupakan kemampuan dalam memberikan pelayanan kepada pelanggan atau pasien secara segera dan tepat (Bustami, 2011; Sastrianegara, 2014), sehingga agar kualitasnya baik atau tidak terletak pada tepat dan cepat dalam melakukan pelayanan. Hal tersebut sangat mempengaruhi penerimaan yang berkelanjutan dan kepatuhan terhadap kunjungan pemeriksaan (Care et al., 2008)

\section{REFERENSI}

Amini, P. et al. (2019) 'The Breastfeeding Self - Efficacy Scale - Short Form ( BSES - SF ): a validation study in Iranian mothers', BMC Research Notes. BioMed Central, pp. 1-6. doi: 10.1186/s13104-019-4656-7.

Bustami (2011) Penjaminan Mutu Pelayanan Kesehatan dan Akseptabilitasnya. Jakarta: Penerbit Buku Erlangga.

Care, A. et al. (2008) 'Clients' Perceptions of the Quality of Antenatal Care', Journal of the

National Medical Association. Elsevier Masson SAS, 100(9), pp. 1052-1058. doi: 10.1016/S0027-9684(15)31443-7.

Do, M. et al. (2017) 'Quality of antenatal care and client satisfaction in Kenya and Namibia',

International Journal for Quality in Health Care, 29(2). doi: 10.1093/intqhe/mzx001.

Heaman, M. I. et al. (2014) 'Quality of prenatal care questionnaire : instrument development and testing', pp. 1-16. 
Mbachu, C., Dim, C. and Ezeoke, U. (2017) 'Effects of peer health education on perception and practice of screening for cervical cancer among urban residential women in south- east Nigeria: A before and after study', BMC Women's Health. BMC Women's Health, 17(1), pp. 1-8. doi: 10.1186/s12905-017-0399-6.

Mikrajab, M. A. and Rachmawati, T. (2016) 'ANALISIS KEBIJAKAN IMPLEMENTASI ANTENATAL CARE TERPADU PUSKESMAS DI KOTA BLITAR (Policy Analysis of Integrated Antenatal Care implementation at Public Health Centers in Blitar City)', Buletin Penelitian Sistem Kesehatan, 19(1), pp. 41-53. doi: 10.22435/hsr.v19i1.4988.41-53.

Moller, A. B. et al. (2017) 'Early antenatal care visit: a systematic analysis of regional and global levels and trends of coverage from 1990 to 2013', The Lancet Global Health, 5(10). doi: 10.1016/S2214-109X(17)30325-X.

Nwaeze, I. L. et al. (2013) 'Perception and satisfaction with quality of antenatal care services among pregnant women at the university college hospital, ibadan, Nigeria.', Annals of Ibadan postgraduate medicine, 11(1), pp. 22-8. Available at: http://www.ncbi.nlm.nih.gov/pubmed/25 161419\%0Ahttp://www.pubmedcentral. nih.gov/articlerender.fcgi?artid=PMC41 11061.

Oladapo, O. T. and Osiberu, Æ. M. O. (2015) 'Do Sociodemographic Characteristics of

Pregnant Women Determine their Perception of Antenatal Care Quality?',(2009), pp.505-511. doi:10.1007/s10995-008-0389-2

Papanikolaou, V. and Zygiaris, S. (2014) 'Service quality perceptions in primary health care entres in Greece', Health Expectations, 17(2), pp. 197-207. doi: 10.1111/j.1369- 7625.2011.00747.x.
Permenkes (2016) Peraturan Menteri Kesehatan RI No 43 Tahun 2016 tentang Standar

Pelayanan Minimal Bidang Kesehatan. Jakarta.

Rahman, M. M., Ngadan, D. P. and Arif, M. T. (2016) 'Factors affecting satisfaction on antenatal care services in Sarawak, Malaysia: evidence from a cross sectional study', SpringerPlus, 5(1). doi: 10.1186/s40064-016-2447-3.

Ravichandran, K. (2010) 'Influence of Service Quality on Customer Satisfaction Application of Servqual Model', Journal of Business and Management, 5(4), pp. 117-125. doi: Article.

Sastrianegara, M. F. (2014) Organisasi dan Manajemen Pelayanan Kesehatan. Jakarta: Penerbit Buku Salemba Medika.

Sudigdo, S. (2011) Dasar-dasar Metodelogi Penelitian Klinis. Edisi keem. Jakarta: Penerbit

Buku Sagung Seto.

Tenkorang, E. Y. (2016) 'Type of Health Facility and Utilization of Antenatal Care Services Among Ghanaian Women', Population Research and Policy Review. Springer Netherlands, 35(5), pp. 631-650. doi: 10.1007/s11113-016-9406-0.

WHO (2016) 'WHO recommendations on antenatal care for a positive pregnancy experience'.

Hulley, S. (2007) Designing Clinical Research. Edisi tiga. Philadelphia USA. Manzi, A. et al. (2018) 'Beyond coverage: Improving the quality of antenatal care delivery through integrated mentorship and quality improvement at health centers in rural Rwanda', BMC Health Services Research. BMC Health Services Research, 18(1), pp. 1-8. doi: 10.1186/s12913-018-2939-7 